\title{
Selective Oxidative Carbonylation of Aniline to Diphenylurea with lonic Liquids
}

\author{
Zahrtmann, Nanette; Claver, Carmen; Godard, Cyril; Riisager, Anders; Garcia Suárez, Eduardo José
}

Published in:

ChemCatChem

Link to article, DOI:

$10.1002 /$ cctc. 201800004

Publication date:

2018

Document Version

Peer reviewed version

Link back to DTU Orbit

Citation (APA):

Zahrtmann, N., Claver, C., Godard, C., Riisager, A., \& Garcia Suárez, E. J. (2018). Selective Oxidative Carbonylation of Aniline to Diphenylurea with lonic Liquids. ChemCatChem, 20, 2450-2457.

https://doi.org/10.1002/cctc.201800004

\section{General rights}

Copyright and moral rights for the publications made accessible in the public portal are retained by the authors and/or other copyright owners and it is a condition of accessing publications that users recognise and abide by the legal requirements associated with these rights.

- Users may download and print one copy of any publication from the public portal for the purpose of private study or research.

- You may not further distribute the material or use it for any profit-making activity or commercial gain

- You may freely distribute the URL identifying the publication in the public portal 
Heterogeneous \& Homogeneous \& Bio- \& NanoCHEMCATCHEM CATALYSIS

\section{Accepted Article}

Title: Selective Oxidative Carbonylation of Aniline to Diphenylurea with Ionic Liquids

Authors: Nanette Zahrtmann, Carmen Claver, Cyril Godard, Anders Riisager, and Eduardo José Garcia-Suárez

This manuscript has been accepted after peer review and appears as an Accepted Article online prior to editing, proofing, and formal publication of the final Version of Record (VoR). This work is currently citable by using the Digital Object Identifier (DOI) given below. The VoR will be published online in Early View as soon as possible and may be different to this Accepted Article as a result of editing. Readers should obtain the VoR from the journal website shown below when it is published to ensure accuracy of information. The authors are responsible for the content of this Accepted Article.

To be cited as: ChemCatChem 10.1002/cctc.201800004

Link to VoR: http://dx.doi.org/10.1002/cctc.201800004 
WILEY-VCH

\title{
Selective Oxidative Carbonylation of Aniline to Diphenylurea with
}

\section{lonic Liquids}

\author{
N. Zahrtmann, ${ }^{[a, b]}$ C. Claver, ${ }^{[a]}$ C. Godard,,${ }^{[a] *}$ A. Riisager, ${ }^{[b] *}$ and E.J. Garcia-Suarez ${ }^{[b, c, d]}$
}

Abstract: A catalytic system for the selective oxidative carbonylation of aniline to diphenylurea based on Pd complexes in combination with imidazolium ionic liquids is presented. Both oxidants, $\mathrm{Pd}$ complexes and ionic liquids affect the activity of the reaction while the choice of oxidant determines the selectivity of the reaction. Together they allows the reaction to proceed under comparatively mild conditions without loss of activity. In-situ NMR examination of the reaction led to the observation of a previously suggested intermediate supporting the proposed mechanism.

\section{Introduction}

Ureas are commonly found in the structures of a large number of biologically active compounds. Moreover, ureic derivatives have a wide spectrum of biological activity and have been extensively applied as agrochemicals, dyes, antioxidants or resin precursors as well as key intermediates in organic synthesis, e.g. in the production of isocyanates. ${ }^{[1]}$ In this context, the oxidative carbonylation of amines to obtain ureas (Scheme 1) has received much interest over the past 50 years ${ }^{[2]}$ as alternative to the traditional phosgenation process. ${ }^{[3]}$ The reaction is carried out in the presence of a metal catalyst or organo-catalyst, an oxidizing agent such as $\mathrm{I}_{2}{ }^{[1,4]}$ or $\mathrm{O}_{2} / \mathrm{Air}^{[5]}$ and $\mathrm{CO}$ pressure. Among the transition metals and organo-catalysts $\mathrm{Mn},{ }^{[2]} \mathrm{Pd},{ }^{[4 c, 5 h-q, 6]} \mathrm{Cu},{ }^{[5 a, 7]}$ $\mathrm{Au},{ }^{[5 b-c]} \mathrm{Co},{ }^{[5 d-e]} \mathrm{W}^{[1,4 a-b]} \mathrm{Ni},{ }^{[5]} \mathrm{Rh},{ }^{[5 g]} \mathrm{Ru},{ }^{\left[{ }^{[h]}\right]} \mathrm{S}^{[8]}$ and $\mathrm{Se}^{\left[{ }^{[9]}\right.}$ can be pointed out. Usually, a non-nucleophilic solvent is required in order to avoid the formation of carbamates. ${ }^{[5 \mathrm{~h}, 10]}$ The best result reported to date in terms of turn- over-frequency (TOF) was achieved with a catalytic system comprising $\mathrm{Pd}(\mathrm{OAc})_{2}$ and 3butyl-1,2-methylimidazolium iodide as co-catalyst in the presence of $\mathrm{O}_{2}\left(17,368 \mathrm{~h}^{-1}\right)$. However, the reaction was carried out under explosive $\mathrm{CO} / \mathrm{O}_{2}$ gas mixture requiring extraordinary safety precautions. ${ }^{[\mathrm{ij}]}$

$$
2 R^{-}{ }^{-H_{2}} \underset{\mathrm{CO}+{ }^{1 / 2} \mathrm{O}_{2}}{\stackrel{\text { catalyst }}{\longrightarrow}} R^{-\stackrel{H}{N}} \prod_{\mathrm{O}}^{\stackrel{H}{N}}+\mathrm{H}_{2} \mathrm{O}
$$

Scheme 1. General reaction scheme for the oxidative carbonylation of amines to ureas.

[a] Dr. N. Zahrtmann, Prof. C. Claver and Prof. Cyril Godard Department of Physical and Inorganic Chemistry, Universitat Rovira I Virgili, C/Marcel.li Domingo s/n, Campus Sescelades, 43007 Tarragona (Spain), E-mail: cyril.godard@urv.cat

[b] Dr. N. Zahrtmann, Prof. A. Riisager and Dr. E.J. García-Suárez Centre for Catalysis and Sustainable Chemistry, Department of Chemistry, Technical University of Denmark, DK-2800 Kgs. Lyngby (Denmark), E-mail: ar@kemi.dtu.dk

[c] Tecnalia. Energy and Environment Division. Parque Tecnológico de Álava, Leonardo Da Vinci, 11, 01510 Miñano, Spain.

[d] IKERBASQUE, Basque Foundation for Science, Maria Diaz de Haro 3, 48013 Bilbao, Spain
The mechanism of the $\mathrm{Pd}$-catalysed oxidative carbonylation of amines have been studied by Hiwatari et al. ${ }^{[6]]}$ using $I_{2}$ as oxidant (Scheme 2). The authors suggested that the reaction proceeds through a $\mathrm{Pd}^{2+} / \mathrm{Pd}^{0}$-cycle via a $\mathrm{Pd}$-carbamoyl intermediate, where the active species is a $\mathrm{Pd}^{2+}$ complex (I) that reacts with $\mathrm{CO}$ and 2 equivalents of amine to form a $\mathrm{Pd}$ carbamoyl complex (II) and an ammonium salt. Reaction of an amine molecule at the carbonyl of Pd intermediate (II) provides the corresponding isocyanate that reacts in-situ to form urea as final product and $\mathrm{Pd}^{0}$ species (III) that are reoxidized to the actives $\mathrm{Pd}^{2+}$ species (I).

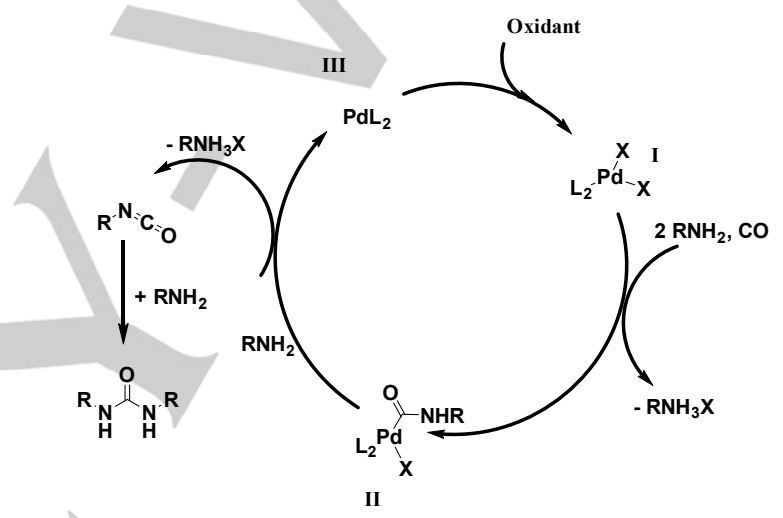

Scheme 2. Mechanism proposed by Hiwatari and co-workers for the Pdcatalysed oxidative carbonylation of amines. ${ }^{[6 \mathrm{~d}]}$

The basis of the mechanism suggested by Hiwatari et al. is the observation, that the isolated $\mathrm{N}$-propylcarbamoyl-Pd complex reacts with primary and secondary amines yielding $N, N$ dialkylurea and $N, N, N$-trialkylurea, respectively, while the reaction with a tertiary amine forms the free isocyanate (Scheme 2). The selectivity of the reaction supports the mechanism as the reaction step II to III can be promoted by primary, secondary and tertiary amines alike although isocyanate can only be formed from a primary amine and the formation of the urea from isocyanate requires a primary or a secondary amine. The repeated observation that $\mathrm{N}, \mathrm{N}, \mathrm{N}, \mathrm{N}$-tetrasubstituded ureas cannot be generated with $\mathrm{CO}$ and secondary amines as the only substrates $^{[51-0]}$ supports this mechanism. On the other hand, a different mechanism must be accredited for the observations published first by Pri-Bar et al. ${ }^{[4 c]}$ and later by others ${ }^{[4 d-f]}$ who prepared $\mathrm{N}, \mathrm{N}, \mathrm{N}, \mathrm{N}$-tetrasubstituted ureas in $\mathrm{I}_{2}$-oxidised systems. Giannoccaro et al. ${ }^{[4 \mathrm{~d}, 5 q]}$ prepared Pd-carbamoyl complexes of both primary and secondary aliphatic amines from various $\mathrm{Pd}(\mathrm{L}-$ $\mathrm{L}) \mathrm{Cl}_{2}$ precursors and isolated the $\mathrm{Pd}$-complexes along with ammonium chlorides supporting the mechanistic proposal by Hiwatari et al. ${ }^{[\mathrm{d}]}$ The Pd-carbamoyl complexes were subsequently treated with $\mathrm{Cl}_{2}, \mathrm{I}_{2}$ and $\mathrm{CuCl}_{2}$ yielding various elimination products along with the $\mathrm{Pd}^{2+}$ precursors. ${ }^{[4 d, 5 q]}$ The elimination products were found to be more dependant of the amine substitution than the halide source as secondary 
carbamoyl halides and primary isocyantes was formed regardless of halide source. Giannoccaro et al. ${ }^{[5]]}$ summarized their observations in a proposed mechanism which is largely in agreement with the proposal made by Hiwatari et al., ${ }^{[6 \mathrm{~d}]}$ although they disagree on whether or not the ammonium halides reenter the cycle. The formation of secondary carbamoyl halides would explain the observation of $\mathrm{N}, \mathrm{N}, \mathrm{N}, \mathrm{N}$-tetraalkylureas in reactions where $I_{2}$ have been used as oxidant as the reaction of carbamoyl halides with nucleophiles is well known. ${ }^{[11]}$ Further support for the proposed mechanisms have been provided by Didgikar et al. ${ }^{[5 \mathrm{~m}]}$ and Gabriele et al. ${ }^{[5 k-1,5 n-m]}$ who both studied the oxidative carbonylation of amines with $\mathrm{Pd}^{2+} / l^{-}$catalytic systems using $\mathrm{O}_{2}$ as oxidant, and reported a correlation between the nucleophilicity and the reactivity of the substrate.

lonic liquids (ILs) have been employed as reaction media in the oxidative carbonylation of amines generating biphasic systems. ${ }^{[5 i, 5 k]}$ In these reactions, the catalytic systems were constituted by a $\mathrm{Pd}^{2+}$ catalysts, an IL - and in the case of Mancuso et al. - an iodide salt as additive. ${ }^{[5 k]}$ ILs constitute a special class of compounds that exhibit interesting physical and chemical properties for application in catalysis, biomass processing, electrochemistry etc. ${ }^{[12]}$ In catalysis, ILs can be used as both reaction media and catalysts and provide beneficial effects such as, e.g. high stability towards oxidation by $\mathrm{O}_{2} \cdot{ }^{[12 c]}$ In addition, ILs can be easily functionalized for specific catalytic applications. ${ }^{[12 c-}$ e]

In this work, we report the use of Pd-based catalysts bearing $\mathrm{N}$ - or $\mathrm{P}$-donor ligands for the selective oxidative carbonylation of aniline into diphenylurea in the presence of IL as reaction media. The roles of the IL ions, ligands, oxidants as well as the effect of catalyst loading were investigated and optimized. Introduction of a highly active catalytic system, even under comparatively mild conditions, and observation of the Pd-carbamoyl intermediate previously suggested by Hiwatari and Giannoccaro et al. (vide supra) by in-situ NMR spectroscopy, along with a TOF of 15,000 under optimized conditions, are prominent results obtained in the reported study.

\section{Results and Discussion}

\section{Influence of oxidant, catalyst loading and reaction time}

The influence of the oxidant is important for oxidative carbonylation. $\mathrm{O}_{2}$ is preferred as a green oxidant but some safety issues have to be considered, i.e. choice of organic solvent due to peroxide formation (e.g. THF or 1,4-dioxane) and concentration of $\mathrm{O}_{2}$ in the $\mathrm{CO} / \mathrm{O}_{2}$ mixtures to avoid potential explosive hazards. ${ }^{[12 e]}$ With this in mind, $\mathrm{O}_{2}, \mathrm{I}_{2}$ and 1,4-benzoquinone (BQ) were selected as oxidants in the study. Noteworthy, $B Q$ was used as oxidant for the first time for this reaction type although it has been employed in other well-known Pd-catalyzed processes such as olefins carbonylation. ${ }^{[13]}$ The reaction was initially carried out in a biphasic mixture of toluene and 1-butyl-3-methylimidazolium chloride $([\mathrm{BMIM}] \mathrm{Cl})$ at $140{ }^{\circ} \mathrm{C}$ under 10 bar of $\mathrm{CO}$ using $0.1 \mathrm{~mol} \%$ of $\mathrm{Pd}\left(\mathrm{PPh}_{3}\right)_{2} \mathrm{Cl}_{2}$ as catalyst. The results are displayed in Table 1.
After $4 \mathrm{~h}$ of reaction, full conversion aniline was achieved with $\mathrm{BQ}$ and $\mathrm{I}_{2}$ as oxidants while only $79 \%$ conversion was obtained with $\mathrm{O}_{2}$ (Table 1, entries 1-4). The lower conversion in the case of $\mathrm{O}_{2}$ was attributed to the poor solubility of the gas in the reaction media ${ }^{[14]}$ Concerning the selectivity, more than $99 \%$ diphenylurea was formed with $\mathrm{BQ}$ and $\mathrm{O}_{2}$ as oxidants (entries 3 and 4). In contrast, no urea product was obtained when $\mathrm{I}_{2}$ was used without additional additives instead only anilinium chloride formed (entry 1). The absence of urea product with $I_{2}$ as oxidant was most likely due to the insolubility of the anilinium chloride species formed from in-situ generated anilinium iodide ${ }^{[5 \mathrm{~m}]}$ and $[\mathrm{BMIM}] \mathrm{Cl}$ during the reaction in the IL phase containing the catalyst, thus hampering the catalytic performance. Similar results were previously reported when $\mathrm{I}_{2}$ was used as oxidant in the absence of additional base..$^{[4-d, 5 k]}$ When the reaction was performed in the presence of $\mathrm{K}_{2} \mathrm{CO}_{3}$ (1 eqivalent), the conversion decreased to $66 \%$ but resulted in $>99 \%$ selectivty towards urea product (entry 2 ) as the base scavange $\mathrm{HI}$ which would otherwise be formed in stociometric amount with respec to urea.

Table 1. Influence of the oxidant, catalyst loading and reaction time. ${ }^{[a]}$

\begin{tabular}{|c|c|c|c|c|c|c|}
\hline Entry & $\begin{array}{l}\text { Catalyst } \\
(\mathrm{mol} \%)\end{array}$ & Oxidant & $\begin{array}{l}\text { Time } \\
\text { (h) }\end{array}$ & $\begin{array}{l}\operatorname{TOF}^{[b]} \\
\left(h^{-1}\right)\end{array}$ & $\begin{array}{l}\text { Conv. }{ }^{[c]} \\
(\%)\end{array}$ & $\begin{array}{l}\text { Selec. }{ }^{[\mathrm{d}]} \\
(\%)\end{array}$ \\
\hline 1 & 0.1 & $\mathrm{I}_{2}$ & 4 & 248 & 99 & 0 \\
\hline $2^{[e]}$ & 0.1 & $\mathrm{I}_{2}$ & 4 & 165 & 66 & $>99$ \\
\hline 3 & 0.1 & $\mathrm{O}_{2}$ & 4 & 198 & 79 & $>99$ \\
\hline 4 & 0.1 & $B Q$ & 4 & 250 & 100 & $>99$ \\
\hline 5 & - & $B Q$ & 1 & 0 & 0 & - \\
\hline 6 & 0.001 & $B Q$ & 1 & 11,000 & 11 & $>99$ \\
\hline 7 & 0.005 & $B Q$ & 1 & 7,200 & 36 & $>99$ \\
\hline 8 & 0.01 & $B Q$ & 1 & 5,200 & 52 & $>99$ \\
\hline 9 & 0.1 & $B Q$ & 1 & 1,000 & 100 & $>99$ \\
\hline 10 & 0.01 & $B Q$ & 0.25 & 15,600 & 39 & $>99$ \\
\hline 11 & 0.01 & $B Q$ & 2 & 2,350 & 47 & $>99$ \\
\hline 12 & 0.01 & $B Q$ & 4 & 1,100 & 44 & $>99$ \\
\hline
\end{tabular}

[a] Reaction conditions: Aniline (6 mmol), $\mathrm{Pd}\left(\mathrm{PPh}_{3}\right)_{2} \mathrm{Cl}_{2}, \mathrm{BQ}$ (benzoquinone) $(6 \mathrm{mmol}), \mathrm{I}_{2}(6 \mathrm{mmol}), \mathrm{O}_{2}(6 \mathrm{mmol}), \mathrm{CO}(0.1 \mathrm{~mol}), 10$ bar total pressure, $[\mathrm{BMIM}][\mathrm{Cl}](7.5 \mathrm{mmol})$, mesitylene as internal standard $(0.6 \mathrm{mmol})$, toluene $(10.5 \mathrm{~mL}), 140{ }^{\circ} \mathrm{C}, 1000 \mathrm{rpm}$. [b] Turn-over-frequency as mmol aniline converted per mmol Pd per hour. [c] Conversion of aniline. [d] Selectivity to diphenylurea. [e] Using $\mathrm{K}_{2} \mathrm{CO}_{3}$ as additive $(6 \mathrm{mmol})$.

Based on the initial results, $B Q$ was selected as oxidant to study the catalyst loading and reaction time effect. When the catalyst loading was progressively decreased from 0.1 to 0.001 mol $\%$, a decrease from full conversion to $11 \%$ was observed while the selectivity towards diphenylurea remained unchanged at 
$>99 \%$ (Table 1, entries 6-9). Similarly, the catalyst turn-overfrequency (TOF) increased significantly with the lower catalyst loadings suggesting that only under these conditions was the catalyst inventory utilized efficiently. The influence of the reaction time was also studied at $0.01 \mathrm{~mol} \%$ catalyst loading (Table 1 , entries 8 and 10-12). After $1 \mathrm{~h}$ reaction time, a maximum conversion of $52 \%$ was achieved whereas longer reaction time resulted in decreased conversions of 47 and $44 \%$ after 2 and $4 \mathrm{~h}$, respectively. These results are possibly explained by partly decomposition of the formed diphenylurea into aniline and phenylisocyanate followed by further decomposition into aniline and $\mathrm{CO}_{2}$ in the presence of water (Scheme 3). ${ }^{[15]}$ It is worth to point out that the studied catalytic system composed of $[\mathrm{BMIM}] \mathrm{Cl} / \mathrm{Pd}-\mathrm{PPh}_{3} / \mathrm{BQ}$ is, to the best of our knowledge, among the most active reported in the literature ${ }^{[5 i-j]}$ with a TOF of 15,600 $\mathrm{h}^{-1}$ after $15 \mathrm{~min}$ reaction (Table 1 , entry 10 ).

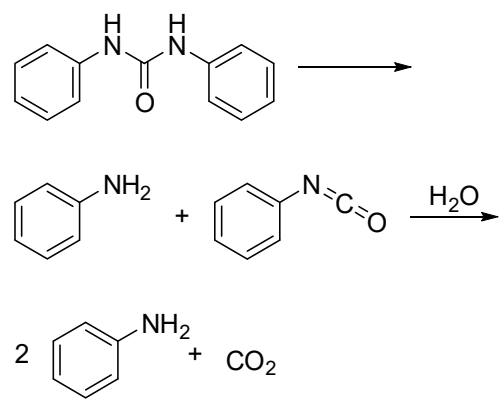

Scheme 3. Diphenylurea decomposition to aniline. ${ }^{[55]}$

\section{Influence of the ligand}

Various Pd-complexes with 1,3-bis(2,6-diisopropyl-phenyl)-1Himidazol-3-ium-2-ide (L1), 1,10-phenantroline (L2), 3chloropyridine, aniline (L3), benzonitrile (L4) and triphenylphosphine (L5) ligands (Figure 1) were next tested in the oxidative carbonylation of aniline to diphenylurea. The catalytic experiments were performed with a catalyst loading of $0.01 \mathrm{~mol} \%$ using the corresponding isolated complexes $\mathrm{Pd}(\mathbf{L} 1)_{2} \mathrm{Cl}_{2}$, $\mathrm{Pd}(\mathbf{L} 1)(3-\mathrm{Cl}$-pyridine $) \mathrm{Cl}_{2}, \mathrm{Pd}(\mathbf{L} 2) \mathrm{Cl}_{2}, \mathrm{Pd}(\mathbf{L} 3)_{2} \mathrm{Cl}_{2}, \mathrm{Pd}(\mathbf{L} 4)_{2} \mathrm{Cl}_{2}$, and $\mathrm{Pd}(\mathbf{L} 5)_{2} \mathrm{Cl}_{2}$ synthesized according to previous reports. ${ }^{[16]}$ The results obtained are displayed in Figure 2.

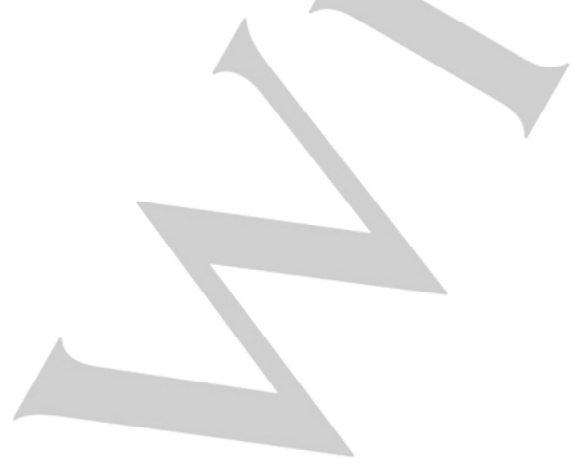

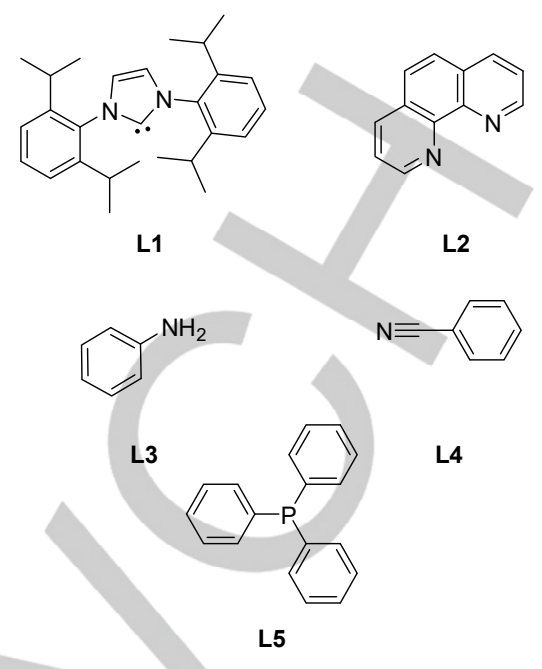

Figure 1. Ligands tested in the oxidative carbonylation of aniline.

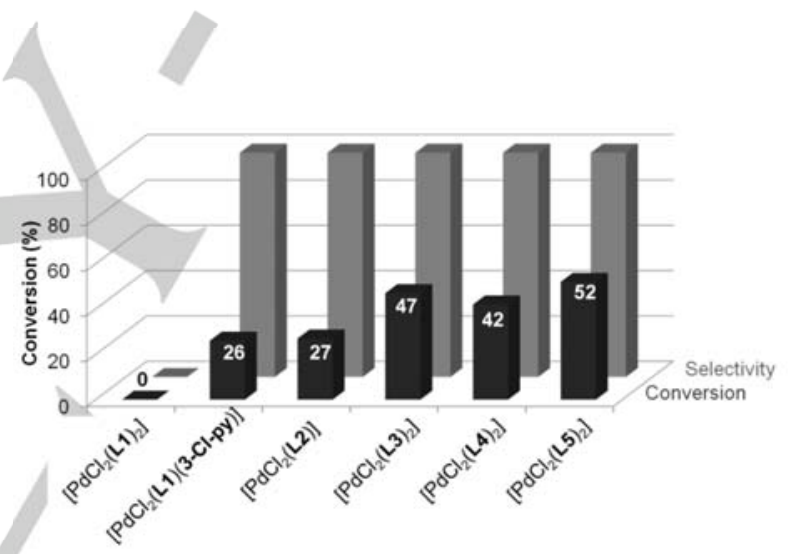

Figure 2. Influence of the ligand in the selective oxidative carbonylation of aniline to diphenylurea. Reaction conditions: Aniline $(6 \mathrm{mmol})$, Pd-complex $(0.01 \mathrm{~mol} \%), \mathrm{BQ}(6 \mathrm{mmol}), \mathrm{CO}(0.1 \mathrm{~mol}), 10$ bar total pressure, [BMIM]Cl $(7.5$ $\mathrm{mmol})$, mesitylene as internal standard $(0.6 \mathrm{mmol})$, toluene $(10.5 \mathrm{~mL}), 140^{\circ} \mathrm{C}$, $1 \mathrm{~h}$.

The highest aniline conversion (52\%) was achieved when the $\mathrm{Pd}(\mathbf{L} 5)_{2} \mathrm{Cl}_{2}$ complex was used, whereas slightly lower conversions $(47 \%$ and $42 \%)$ were obtained with the two complexes $\mathrm{Pd}(\mathbf{L} 3)_{2} \mathrm{Cl}_{2}$ and $\mathrm{Pd}(\mathbf{L} 4)_{2} \mathrm{Cl}_{2}$ bearing the monodentate $\mathrm{N}$-donor ligands. The similar results obtained with the latter complexes was probably due to fast replacement of L4 by L3 (substrate) resulting in in-situ formation of the same catalytically active Pd-L3 species. When the PEPPSI complex Pd(L1)(3-Clpyridine $) \mathrm{Cl}_{2}$ and $\mathrm{Pd}(\mathbf{L} 2) \mathrm{Cl}_{2}$ were tested, lower but also similar conversions ( $26 \%$ and $27 \%$, respectively) were obtained. The low conversion obtained with ligand L2 was somehow unexpected, since very good results were obtained by Shi et al. although under more harsh reaction conditions $\left(175^{\circ} \mathrm{C}\right.$ and 50 bar $\left.\mathrm{CO}\right) .{ }^{[17]}$ The $\mathrm{Pd}(\mathrm{L} 1)_{2} \mathrm{Cl}_{2}$ complex bearing two NHC ligands showed no activity at all in agreement with previous reports. ${ }^{[16 g-h]}$ Considering the catalytic behavior which have been reported for bis-Pd(NHC)- 
complexes an isomerisation from trans- to cis-configuration is required for the addition of the substrate. ${ }^{[18]}$ Given the inflexibility of the applied carbene ligands ${ }^{[19]}$ this isomerisation is unlikely to take place thus blocking the coordination of the substrate.

In order to elucidate why $\mathrm{Pd}\left(\mathrm{PPh}_{3}\right)_{2} \mathrm{Cl}_{2}$ was the most active pre-catalyst complex, a high pressure (HP) NMR study was performed with this system under in-situ conditions applying ${ }^{13} \mathrm{C}\left\{{ }^{1} \mathrm{H}\right\}$ - and ${ }^{31} \mathrm{P}\left\{{ }^{1} \mathrm{H}\right\}-N M R$. At the beginning of the experiment, the ${ }^{31} \mathrm{P}\left\{{ }^{1} \mathrm{H}\right\}-N M R$ spectrum (Figure 3 , trace 1 ) displayed one signal at $\delta=24.30 \mathrm{ppm}$ in agreement with the characterization of the pure compound. ${ }^{[16 \mathrm{~b}]}$ The addition of aniline caused no change in the spectrum (trace 2), while heating the mixture under $\mathrm{Ar}$ lead to a broadening of the signal and an up-field shift to $\delta=23.86 \mathrm{ppm}$ (trace 3). No signals belonging to free $\mathrm{PPh}_{3}$ (or $\mathrm{O}=\mathrm{PPh}_{3}$ ) were observed, indicating that the complex was stable under these conditions. Upon the addition of $\mathrm{CO}$ gas (trace 4) a signal was immediately observed at $\delta=-4.70 \mathrm{ppm}$, assigned to uncoordinated $\mathrm{PPh}_{3}$ in agreement with literature. ${ }^{[72]}$ Heating the reaction mixture under $\mathrm{CO}$ to $80^{\circ} \mathrm{C}$ (trace 5) lead to a broadening of the signals to an extent where the ligand signal almost disappeared into the background but, in addition, it also resulted in formation of new signal at $\delta=24.82 \mathrm{ppm}$. Heating to $110{ }^{\circ} \mathrm{C}$ (trace 6) caused the signals of both free $\mathrm{PPh}_{3}$ and $\mathrm{Pd}\left(\mathrm{PPh}_{3}\right)_{2} \mathrm{Cl}_{2}$ to increase in intensity and width indicating rapid ligand exchange on the metal centre. Furthermore, new signals were observed at $\delta=25.16$ and $19.79 \mathrm{ppm}$. Cooling the sample to $25^{\circ} \mathrm{C}$ (trace 7) resulted eventually in three distinct signals at $\delta=26.64,24.30$ and 19.54 ppm assignable to $\mathrm{PdCO}_{n}\left(\mathrm{PPh}_{3}\right)_{\times}{ }^{[20]} \mathrm{PdCl}_{2}\left(\mathrm{PPh}_{3}\right)_{2} \mathrm{Cl}_{2}{ }^{[16 b, 20 \mathrm{a}]}$ and $\mathrm{PdCl}(\mathrm{CONHPh})\left(\mathrm{PPh}_{3}\right)_{2},{ }^{[6 \mathrm{~d}]}$ respectively.

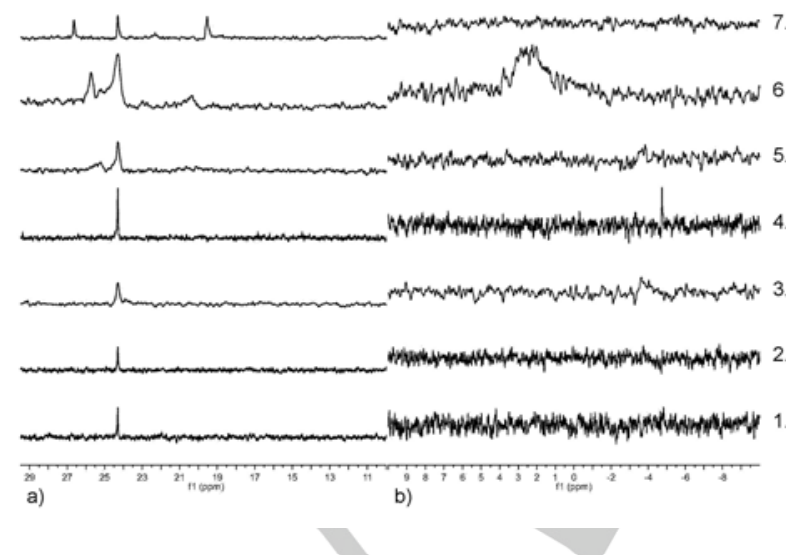

Figure 3. In-situ ${ }^{31} \mathrm{P}\left\{{ }^{1} \mathrm{H}\right\}-\mathrm{NMR}$ (sapphire tube, $162 \mathrm{MHz}$, toluene) of the $\mathrm{Pd}\left(\mathrm{PPh}_{3}\right)_{2} \mathrm{Cl}_{2}$ catalysed carbonylation of aniline before, under and after formation of diphenylurea. (1) Initial spectra of $\mathrm{Pd}\left(\mathrm{PPh}_{3}\right)_{2} \mathrm{Cl}_{2} /[\mathrm{BMIM}] \mathrm{Cl}$ suspension under $\operatorname{Ar}$ at $25^{\circ} \mathrm{C}$, (2) after the addition aniline under $\operatorname{Ar}$ at $25^{\circ} \mathrm{C}$ (3) the reaction mixture at $80^{\circ} \mathrm{C}$ under $\mathrm{Ar}$, (4) the reaction mixture under 5 bar $\mathrm{CO}$ at $25^{\circ} \mathrm{C}$, (5) the reaction mixture under $\mathrm{CO}$ at $80^{\circ} \mathrm{C},(6)$ the reaction mixture under $\mathrm{CO}$ at $110{ }^{\circ} \mathrm{C}$ and $(7)$ the reaction mixture under $\mathrm{CO}$ at $25^{\circ} \mathrm{C}$. a, b: b is shown with a five-fold intensity with respect to $a$.

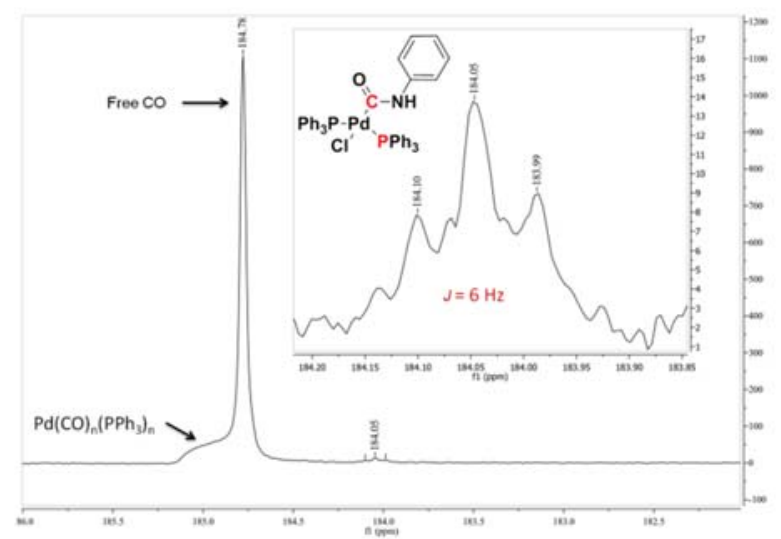

Figure 4. In-situ ${ }^{31} \mathrm{C}\left\{{ }^{1} \mathrm{H}\right\}-\mathrm{NMR}$ (sapphire tube, $100 \mathrm{MHz}$, toluene, $25^{\circ} \mathrm{C}, 5 \mathrm{bar}$ $\left.{ }^{12} \mathrm{CO}:{ }^{13} \mathrm{CO}=3: 2\right)$ of the $\mathrm{Pd}\left(\mathrm{PPh}_{3}\right)_{2} \mathrm{Cl}_{2}$ catalysed carbonylation of aniline after the formation of diphenylurea.

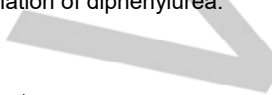

${ }^{13} \mathrm{C}\left\{{ }^{1} \mathrm{H}\right\}$-spectra were also recorded before, under and after the HP-NMR experiment. Figure 4 shows the $\delta=186-182 \mathrm{ppm}$ range of the spectrum recorded at the end of the experiment after cooling. It featured free $\mathrm{CO}$ at $\delta=184.8 \mathrm{ppm}$ with a shoulder at $\delta$ $\approx 185 \mathrm{ppm}$ as the most dominant signals and a triplet at $\delta=184.0$ ppm which was assigned to the $\mathrm{Pd}$-carbamoyl complex. ${ }^{[6 \mathrm{~d}]}$

The stability and reactivity of $\mathrm{Pd}\left(\mathrm{PPh}_{3}\right)_{2} \mathrm{Cl}_{2}$ correlated well with the results obtained during catalytic testing. As $\mathrm{PPh}_{3}$ do not interchange with aniline even at elevated temperatures, the improved conversion obtained with $\mathrm{Pd}\left(\mathrm{PPh}_{3}\right)_{2} \mathrm{Cl}_{2}$ as catalyst is directly related to the coordination of $\mathrm{PPh}_{3}$. Under an atmosphere of $\mathrm{CO}$ and with heating to $110^{\circ} \mathrm{C}, \mathrm{Pd}\left(\mathrm{PPh}_{3}\right)_{2} \mathrm{Cl}_{2}$ underwent a rapid exchange of $\mathrm{PPh}_{3}$ and $\mathrm{CO}$ at the metal center, which activated the complex for the formation of the Pd-carbamoyls intermediate proposed by Hiwatari et al. ${ }^{[\mathrm{bd}]}$ and Giannocarro et al. ${ }^{[5 q]}$ To the best of our knowledge, it is the first time the Pdcarbamoyl complex have been observed under in-situ conditions.

\section{Influence of pressure with $\mathrm{O}_{2}$ as oxidant}

Initial results using $\mathrm{O}_{2}$ as an oxidant, indicated that low solubility of $\mathrm{O}_{2}$ in the IL caused incomplete conversion of the aniline in the reaction system (Table 1 , entry 3 ). Optimization of the stirring rate was therefore important to maximize gas solubility. Accordingly, the influence of stirring rate was examined for the $\mathrm{Pd}\left(\mathrm{PPh}_{3}\right)_{2} \mathrm{Cl}_{2}$ catalyst system using $\mathrm{O}_{2}$ as oxidant and the results are shown in Table 2 (entries 1-3). Increase in conversion from $41 \%$ to $79 \%$ was observed when the stirring rate was increased from 500 to $1,000 \mathrm{rpm}$, but further increase in the stirring rate to $1,400 \mathrm{rpm}$ did not provide any improvement in conversion. This fact confirmed that mass transfer of $\mathrm{O}_{2}$ was rate limiting only with stirring rates below $1000 \mathrm{rpm}$. 
Table 2. Influence of the stirring rate and catalyst loading. ${ }^{[a]}$

\begin{tabular}{llllll}
\hline Entry & $\begin{array}{l}\text { Catalyst } \\
(\mathrm{mol} \%)\end{array}$ & $\begin{array}{l}\text { Stirring } \\
(\mathrm{rpm})\end{array}$ & $\begin{array}{l}\text { TOF } \\
\left(\mathrm{h}^{-1}\right)^{[\mathrm{b}]}\end{array}$ & $\begin{array}{l}\text { Conv. } \\
(\%)^{[\mathrm{c}]}\end{array}$ & $\begin{array}{l}\text { Selec. } \\
(\%)^{[\mathrm{d}]}\end{array}$ \\
\hline 1 & 0.1 & 500 & 103 & 41 & $>99$ \\
2 & 0.1 & 1,000 & 198 & 79 & $>99$ \\
3 & 0.1 & 1,400 & 195 & 78 & $>99$ \\
4 & - & 1,000 & 0 & 0 & - \\
5 & 0.01 & 1,000 & 1,900 & 76 & $>99$ \\
6 & 0.2 & 1,000 & 98 & 78 & $>99$ \\
7 & 0.5 & 1,000 & 40 & 79 & $>99$ \\
8 & 1 & 1,000 & 18 & 70 & $>99$ \\
9 & 10 & 1,000 & 2 & 82 & $>99$ \\
\hline
\end{tabular}

[a] Reaction conditions: Aniline (6 mmol), $\mathrm{Pd}\left(\mathrm{PPh}_{3}\right)_{2} \mathrm{Cl}_{2}, \mathrm{O}_{2}(6 \mathrm{mmol}), \mathrm{CO}(0.1$ mol), 10 bar total pressure, [BMIM]Cl $(7.5 \mathrm{mmol})$, mesitylene as internal standard $(0.6 \mathrm{mmol})$, toluene $(10.5 \mathrm{~mL}), 140^{\circ} \mathrm{C}, 4 \mathrm{~h}$. [b] Turn-over-frequency as mmol aniline converted per mmol Pd per hour. [c] Conversion of aniline. [d] Selectivity to diphenylurea.

Next, the catalyst loading was optimized between 0.01 and 10 mol\% (Table 2, entries 5-9). The results showed that there was no direct correlation between catalyst loading and conversion with $\mathrm{O}_{2}$ as oxidant, which was in contrast with the results obtained with BQ (Table 1, entries 6-9). Therefore, it appeared that the oxidative carbonylation under the applied reaction conditions was not first order with respect to the catalyst using $\mathrm{O}_{2}$ as oxidant.

Table 3. Influence of IL amount and reaction pressure. ${ }^{[a]}$

\begin{tabular}{llllll}
\hline Entry & $\begin{array}{l}\text { Pressure } \\
(\text { bar })\end{array}$ & $\begin{array}{l}\text { IL } \\
\text { loading } \\
(\mathrm{mmol})\end{array}$ & $\begin{array}{l}\text { TOF } \\
\left(\mathrm{h}^{-1}\right)^{[\mathrm{b}]}\end{array}$ & $\begin{array}{l}\text { Conversion } \\
(\%)^{[\mathrm{c}]}\end{array}$ & $\begin{array}{l}\text { Selectivity } \\
(\%)^{[\mathrm{d}]}\end{array}$ \\
\hline 1 & 5 & 7.5 & 138 & 55 & $>99$ \\
2 & 10 & 7.5 & 198 & 79 & $>99$ \\
3 & 20 & 7.5 & 200 & 80 & $>99$ \\
4 & 30 & 7.5 & 208 & 83 & $>99$ \\
5 & 10 & 15 & 215 & 86 & $>99$ \\
6 & 10 & 30 & 250 & 100 & $>99$ \\
7 & 10 & 0 & 5 & 2 & $\mathrm{n} / \mathrm{a}$ \\
\hline
\end{tabular}

[a] Reaction conditions: Aniline (6 mmol), $\mathrm{Pd}\left(\mathrm{PPh}_{3}\right)_{2} \mathrm{Cl}_{2}(0.1 \mathrm{~mol} \%), \mathrm{O}_{2}(6$ $\mathrm{mmol}), \mathrm{CO},[\mathrm{BMIM}] \mathrm{Cl}$, mesitylene as internal standard $(0.6 \mathrm{mmol})$, toluene $(10.5 \mathrm{~mL}), 140^{\circ} \mathrm{C}, 4 \mathrm{~h}, 1000 \mathrm{rpm}$. [b] Turn-over-frequency as mmol aniline converted per mmol Pd per hour. [c] Conversion of aniline. [d] Selectivity to diphenylurea.
The catalytic performance with varied pressures was also investigated using total pressures of 5-30 bar (Table 3, entries 14). An increase in conversion from 55 to $79 \%$ was obtained when the total pressure was increased from 5 to 10 bar, whereas further pressure increase to 20 or 30 bar did not improve conversion.

The influence of the amount of IL added in the reaction system was also examined (Table 3, entries 2, 5-7). It was here confirmed, that IL addition improved conversion without affecting the selectivity, and the conversion was quantitative when $30 \mathrm{mmol}$ of the IL was employed. The promoting effect of the IL on the reaction indicated an interaction between the $\mathrm{IL}$ and the substrate, the catalyst or the product. The formation of $\mathrm{Pd}-\mathrm{NHC}$ complexes with Pd-precursors in imidazolium ILs have been reported previously, ${ }^{[5,16 \mathrm{~g}-\mathrm{h}, 21]}$ however given the negative effect observed on the reaction when NHC-complexes was applied (Figure 2, entries 1 and 2) in-situ formation of a Pd-NHC complex was not likely to be related to the promoting effect. With respect to possible interactions with the substrate or the product, the unusually high solubility of diphenylurea in $[\mathrm{BMIM}] \mathrm{Cl}(1: 2 \mathrm{molar}$ ratio) lead us to examine the influence of the nature of the IL.

\section{Influence of ionic liquid with $\mathrm{O}_{2}$ as oxidant}

Physical and chemical properties of ILs are tunable by selecting the appropriate ion combination, which in turn may influence the catalytic performance for a studied reaction. Here, various IL ion compositions were also tested for the oxidative carbonylation of aniline to diphenylurea using the standard reaction conditionsa shown in Figure 5. 1-Butyl-3-methylimidizolium ([BMIM] ${ }^{+}$) was selected as the starting cation in combination with different anions, namely iodide, bistriflimide, bromide and chloride.

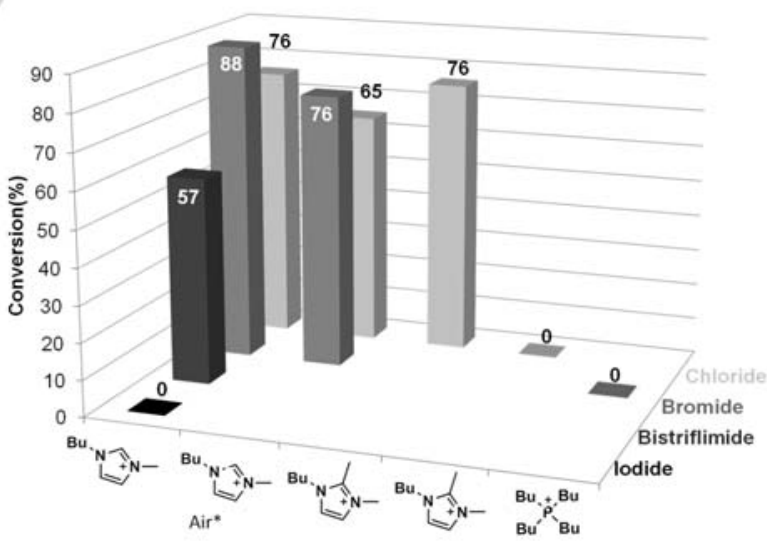

Figure 5. Effect of the IL compostion. Reaction conditions: Aniline (12 mmol), $\mathrm{Pd}\left(\mathrm{PPh}_{3}\right)_{2} \mathrm{Cl}_{2}(0.1 \mathrm{~mol} \%), \mathrm{O}_{2}(12 \mathrm{mmol}), \mathrm{CO}(0.1 \mathrm{~mol}), 10$ bar total pressure, IL $(15 \mathrm{mmol})$, toluene $(21 \mathrm{ml})$, mesitylene as internal standard $(1.2 \mathrm{mmol}), 140{ }^{\circ} \mathrm{C}$, $500 \mathrm{rpm}, 1 \mathrm{~h}$. *10 bar $(6 \mathrm{mmol} \mathrm{O})$.

The best results in terms of conversion were obtained with [BMIM] $\mathrm{Br}$ with up to $88 \%$ conversion, while [BMIM]Cl provided $76 \%$ conversion and [BMIM] $\left.\left(\mathrm{CF}_{3} \mathrm{SO}_{2}\right)_{2} \mathrm{~N}\right] 57 \%$. Notably, [BMIM] 
inhibited completely the catalytic reaction, which was unexpected since both Gabriele et al. ${ }^{[50]}$ and Peng et al. ${ }^{\left[{ }^{i j}\right]}$ have described that iodide to play a key role in the catalytic reaction. Didgikar et al. ${ }^{[\mathrm{m}]}$ optimized the iodide/Pd-ratio and obtained the highest conversion with 5 eq. of iodide promoter with respect to $\mathrm{Pd}$, whereas both higher and lower ratios resulted in lower conversion. Here, the application of [BMIM] gave a iodide/Pd-ratio $>1,000$ suggesting that the high iodide concentration coordinately saturated the catalyst.

The effect of the alkyl substitution on the IL cation was studied comparing results obtained with [BMIM]Cl and [EMIM] Cl (1-butyl3-methyl-imidazolium chloride), which both yielded identical conversion (76\%) (Figure 5). Use of other cations such as [BMMIM] $^{+}$(1-butyl-2,3-dimethylimidazolium) or $[\mathrm{TBP}]^{+}$(tetrabutylpyridinium) resulted in no catalytic activity, suggesting that imidazolium cations unsubstituted in the 2-position was required for the reaction. Among the examined anions, bromide gave the best results but $\left[\left(\mathrm{CF}_{3} \mathrm{SO}_{2}\right)_{2} \mathrm{~N}\right]^{-}$rendered an spontaneous separation of the product and consequently $[\mathrm{BMIM}]\left[\left(\mathrm{CF}_{3} \mathrm{SO}_{2}\right)_{2} \mathrm{~N}\right]$ was selected for examination of catalyst recyclability. Upon recycling of the catalytic system, a large decrease in conversion was observed from $57 \%$ (1st run) to $19 \%$ (2nd run) and to $10 \%$ (3rd run), clearly showing that the catalyst was not very stable under the applied conditions.

The strong influence of the IL cation could be related to the weak acidity of the C2-hydrogen of imidazolium, which could facilitate increased solubility of the basic aniline substrate. ${ }^{[22]}$ The acidity of imidazolium ILs are known to be affected by the alkylsubstituents and the ion interactions, ${ }^{[23]}$ which should make [BMIM] $\left.\left(\mathrm{CF}_{3} \mathrm{SO}_{2}\right)_{2} \mathrm{~N}\right]$ the most acidic of the examined ILs and thus better solvent for aniline. ${ }^{[24]}$ However, the weakly coordinating property of the $\left[\left(\mathrm{CF}_{3} \mathrm{SO}_{2}\right)_{2} \mathrm{~N}\right]^{-}$anion might have proven insufficient for stabilizing the $\mathrm{Pd}$-species formed during the catalytic cycle. In combination, these opposite effects probably made [BMIM]Br the best compromise between solvation strength and coordination ability. Additional work are ongoing in order to scrutinize the effects of the ILs in more detail.

\section{Conclusions}

Selective oxidative carbonylation of aniline to diphenylurea $(>99 \%)$ was performed with a catalytic system comprised of $\mathrm{Pd}\left(\mathrm{PPh}_{3}\right)_{2} \mathrm{Cl}_{2}$ and [BMIM]Cl with a TOF of 15,600 and $1,900 \mathrm{~h}^{-1}$ using benzoquinone or $\mathrm{O}_{2}$ as oxidants, respectively. The catalytic activity achieved with the benzoquinone oxidant is, to the best of our knowledge, the highest reported so far under comparatively mild reaction conditions $\left(140^{\circ} \mathrm{C}\right.$ and 10 bar). In addition, HP-NMR experiments provided the first in-situ observation of a suggested Pd-carbamoyl intermediate confirming the trans-conformation of the complex. To investigate the influence of ILs on the reaction, several IL ion compositions were tested and the best results were achieved with $[\mathrm{BMIM}] \mathrm{Br}$ while the employment of $[\mathrm{BMIM}]\left[\left(\mathrm{CF}_{3} \mathrm{SO}_{2}\right)_{2} \mathrm{~N}\right]$ facilitated spontaneous product separation. Recycling experiments with the latter IL showed that the resulting catalytic system was reusable in three consecutive reaction runs but with significant loss of activity which was attributed to instability of the catalytically active Pd-species. Work currently undertaken by our group aims to improve the understanding of the role played by the IL and to optimize the catalytic system to improve its durability.

\section{Experimental Section}

\section{General}

Solvents for synthesis of ILs and Pd-complexes were supplied by Panrec and dried before use with a MBraun MB-SPS- 800 solvent purification system or distilled by standard techniques (acetonitrile and ethyl acetate from $\mathrm{CaH}_{2}$ and THF from $\mathrm{Na}$ /benzophenone). ILs were obtained from Sigma-Aldrich or synthesized by literature method and dried under vacuum $\left(70^{\circ} \mathrm{C},>24 \mathrm{~h}\right)$ prior to use. Syntheses of ligands and $\mathrm{Pd}$-complexes were performed in flamedried glassware under argon using Schlenk technique or in a dry nitrogen glow box when necessary. All other chemicals were supplied by Sigma-Aldrich in analytic grade and used as received. NMR analysis was performed on Bruker, Variant or Oxford 400 $\mathrm{MHz}$ instruments with deuterated solvents (Oxford Isotopes). ${ }^{1} \mathrm{H}$ NMR and ${ }^{13} \mathrm{C}\left\{{ }^{1} \mathrm{H}\right\}$ NMR spectra were referenced to residual solvent peaks as published by Fulmer et al. ${ }^{[25]}\left({ }^{1} \mathrm{H}\right.$ NMR, $400 \mathrm{MHz}$ DMSO: $\delta=2.5(\mathrm{p}, J=3.7,1.8),{ }^{13} \mathrm{C}\left\{{ }^{1} \mathrm{H}\right\}$ NMR, $100 \mathrm{MHz}$ DMSO: $\delta$ = 39.52), while ${ }^{31} \mathrm{P}\left\{{ }^{1} \mathrm{H}\right\}$ NMR spectra was referenced to $\mathrm{H}_{3} \mathrm{PO}_{4}$. GC-MS analysis was performed using an Agilent 220-MS fitted with a HP-5 column $(30 \mathrm{~m} \times 250 \mathrm{~mm} \times 0.25 \mathrm{~mm})$.

\section{Synthesis}

1,3-Bis-(2,6-diisopropylphenyl)imidazolium chloride (iPrHCl) was synthesized following a slightly modified literature procedure. ${ }^{[26]}$ $17.5 \mathrm{~g}(0.1 \mathrm{~mol}) 2,6$-diisopropylaniline were dissolved in $100 \mathrm{ml}$ ethanol in a round-bottomed flask and $7.00 \mathrm{~g}(0.05 \mathrm{~mol}) 40 \mathrm{wt} \%$ aqueous glyoxal solution added followed by three drops of formic acid. After stirring the mixture overnight at room temperature, the bright yellow precipitate (bis-imine) was collected on a porous glass filter, washed with cold methanol and dried. Then, $0.938 \mathrm{~g}$ (31.2 mmol) paraformaldehyde was transferred to a Schlenk flask under argon and $9.4 \mathrm{ml} 4 \mathrm{M} \mathrm{HCl}$ in dioxane (37.5 mol) added. The mixture was stirred until the paraformaldehyde was completely dissolved and the solution turned clear. Afterwards, $5.04 \mathrm{~g} \mathrm{(13.4}$ $\mathrm{mmol}$ ) bis-imine was dissolved in $130 \mathrm{ml}$ of THF in another Schlenk flask under argon and cooled to $0{ }^{\circ} \mathrm{C}$. The paraformaldehyde solution was then transferred to the bis-imine solution via cannula, where after the mixture was allowed to heat to room temperature and left stirring overnight. The precipitated white product was finally collected on a porous glass filter, washed with THF and dried. Yield $2.51 \mathrm{~g} \mathrm{(44 \% ).}{ }^{1} \mathrm{H}$ NMR data corresponded to published data: ${ }^{1} \mathrm{H}$ NMR $\left(400 \mathrm{MHz}, \mathrm{CDCl}_{3}\right) \delta$ $9.88(\mathrm{~s}, 1 \mathrm{H}, \mathrm{N}-\mathrm{CH}-\mathrm{N}), \delta 8.14$ (d, J = 1.6, 2H, N-CH-CH-N), $\delta 7.57$ (t, $J=7.8,2 \mathrm{H}$, phen-p), $\delta 7.35$ (d, $J=7.9,4 \mathrm{H}$, phen-m), $\delta 2.44$ (sep, $J=6.8,4 \mathrm{H}$, me-CH-me), $\delta 1.25$ (dd, $J=4.9,6.1,24 \mathrm{H},-\mathrm{CH}_{3}$ ). 1,3-Bis-(2,6-diisopropylphenyl)imidazolylidene (iPr) was synthesized following a slightly modified published procedure. ${ }^{[27]}$ 
$212.5 \mathrm{mg}(0.5 \mathrm{~mol}) \mathrm{iPrHCl}$ was dispersed in $2 \mathrm{ml}$ THF in a Schlenk flask in the glow box. A solution of $67.3 \mathrm{mg}(0.6 \mathrm{~mol}){ }^{t} \mathrm{BuOK}$ in 5 $\mathrm{ml} \mathrm{THF} \mathrm{was} \mathrm{transferred} \mathrm{to} \mathrm{the} \mathrm{PrHCl}$ solution in the glow box, where after the resulting mixture was stirred for $30 \mathrm{~min}$ and the solvent removed under vacuum. The solid residue was redissolved in hexane, filtered via cannula to another Schlenk flask and dried under vacuum to obtain an opalescent white product. Yield $127 \mathrm{mg}(67 \%) .{ }^{1} \mathrm{H}$ NMR data corresponded to published data: ${ }^{1} \mathrm{H}$ NMR $\left(400 \mathrm{MHz}, \mathrm{THF}-\mathrm{d}_{8}\right) \delta 8.14(\mathrm{~d}, \mathrm{~J}=1.6,2 \mathrm{H}, \mathrm{N}-\mathrm{CH}-$ $\mathrm{CH}-\mathrm{N}), \delta 7.57(\mathrm{t}, \mathrm{J}=7.8,2 \mathrm{H}$, phen-p), $\delta 7.35(\mathrm{~d}, \mathrm{~J}=7.9,4 \mathrm{H}$, phen$\mathrm{m}$ ), $\delta 2.44$ (sep, $\mathrm{J}=6.8,4 \mathrm{H}$, me-CH-me), $\delta 1.25$ (dd, $\mathrm{J}=4.9,6.1$, $\left.24 \mathrm{H},-\mathrm{CH}_{3}\right)$.

$\mathrm{Pd}(\mathrm{PPh})_{2} \mathrm{Cl}_{2}$ was synthesized according to a slightly modified literature procedure. ${ }^{[16 \mathrm{~b}]} 176.3 \mathrm{mg}(0.56 \mathrm{mmol}) \mathrm{Pd}\left(\mathrm{CH}_{3} \mathrm{CN}\right)_{2} \mathrm{Cl}_{2}$ was dissolved in $40 \mathrm{ml}$ dichloromethane in a Schlenk flask under argon and $352.5 \mathrm{mg}(1.3 \mathrm{mmol})$ triphenylphosphine added. The solution was then stirred overnight and the solvent removed under reduced pressure to obtain a crude product, which finally was washed several times with ethanol and diethyl ether followed by drying in vacuum overnight. Yield $356.1 \mathrm{mg}(89 \%) .{ }^{1} \mathrm{H}$ NMR and ${ }^{31} \mathrm{P}\left\{{ }^{1} \mathrm{H}\right\}$ NMR data corresponded to published data: ${ }^{[16 i]}{ }^{1} \mathrm{H}$ NMR (401 MHz, CDCl3) $\delta$ 7.76-7.65 (m, 10H), $\delta$ 7.46-7.34 (m, 20H). ${ }^{31} \mathrm{P}\left\{{ }^{1} \mathrm{H}\right\} \mathrm{NMR}\left(162 \mathrm{MHz}, \mathrm{CDCl}_{3}\right) \delta 24.3$.

$\mathrm{Pd}\left(\right.$ Phen) $\mathrm{Cl}_{2}$ was synthesized by a slightly modified literature procedure. ${ }^{[16 \mathrm{c}]} 64.9 \mathrm{mg}(0.25 \mathrm{mmol}) \quad \mathrm{Pd}\left(\mathrm{CH}_{3} \mathrm{CN}\right)_{2} \mathrm{Cl}_{2}$ was dissolved in $10 \mathrm{ml}$ of dichloromethane in a Schlenk flask. Addition of $45.1 \mathrm{mg}$ (0.25 mmol) 1,10-phenanthroline (Phen) caused immediate precipitation of the product which was collected by filtration, washed in dichloromethane and dried in vacuum to give quantitative yield. ${ }^{1} \mathrm{H}$ NMR data of the product corresponded to published data: ${ }^{[28]}{ }^{1} \mathrm{H}$ NMR $\left(400 \mathrm{MHz}, \mathrm{DMSO}-\mathrm{d}_{6}\right) \delta 9.35(\mathrm{~d}, \mathrm{~J}=$ $5.4,2 \mathrm{H}), \delta 8.14(\mathrm{~d}, \mathrm{~J}=8.2,2 \mathrm{H}), \delta 9.98(\mathrm{~d}, \mathrm{~J}=8.2,2 \mathrm{H}), \delta 8.29$ (s, $2 \mathrm{H})$.

$\mathrm{Pd}(\mathrm{iPr})_{2} \mathrm{Cl}_{2} .12 .6 \mathrm{mg}(0.07 \mathrm{mmol}) \mathrm{PdCl}_{2}$ was suspended in $5 \mathrm{ml}$ THF in a Schlenk flask in the glove box and a solution of $55 \mathrm{mg}$ $(0.14 \mathrm{mmol}) \mathrm{iPr}$ in $20 \mathrm{ml}$ THF was added, which resulted in an immediate color change from dark brown to hazy yellow. After stirring overnight, the solvent was removed under vacuum and the remaining solid purified by column chromatography over silica with 1:1 hexane/ $\mathrm{CH}_{2} \mathrm{Cl}_{2}$ as eluent yielding a light yellow product. Yield $27 \mathrm{mg} \mathrm{(41 \% ).}{ }^{1} \mathrm{H}$ NMR data of the product corresponded to published data: ${ }^{[16 a, 16 g-h] ~}{ }^{1} \mathrm{H}$ NMR $\left(400 \mathrm{MHz}, \mathrm{CDCl}_{3}\right) \delta 7.35(\mathrm{t}, \mathrm{J}=$ 14.0, 4H, Ar-p), $\delta 7.07$ (d, J = 7.6, 8H, Ar-m), $\delta 6.72$ (s, 4H, N-CH$\mathrm{CH}-\mathrm{N}$ ), $\delta 2.88$ (sept, $\mathrm{J}=7.6,8 \mathrm{H}$, me-CH-me), $\delta 0.90$ (t, $\mathrm{J}=7.6$, $\left.24 \mathrm{H},-\mathrm{CH}_{3}\right)$.

$\mathrm{Pd}$ (iPr)(3-chloropyridine) $\mathrm{Cl}_{2}$ was synthesized by a published procedure. ${ }^{[29]} 88.5 \mathrm{mg}(0.5 \mathrm{mmol}) \mathrm{PdCl}_{2}, 234 \mathrm{mg}(0.55 \mathrm{mmol})$ iPrHCl, $345.5 \mathrm{mg}(2.5 \mathrm{mmol}) \mathrm{K}_{2} \mathrm{CO}_{3}$ and $2 \mathrm{ml}(14.8 \mathrm{mmol}) 3-$ chloropyridine was loaded into a Schlenk flask and stirred at $80^{\circ} \mathrm{C}$ overnight. The reaction mixture was cooled to room temperature, diluted with $\mathrm{CH}_{2} \mathrm{Cl}_{2}$ and filtered over celite and silica. Finally, the solvent was removed under vacuum and the oily solid washed with pentane to obtain a light yellow powder product, Yield 286 $\mathrm{mg}(89 \%) .{ }^{1} \mathrm{H}$ NMR data corresponded to published data:[29] ${ }^{1} \mathrm{H}$ $\operatorname{NMR}\left(400 \mathrm{MHz}, \mathrm{CDCl}_{3}\right) \delta 8.60$ (dd, $\left.\mathrm{J}=2.4,0.5,1 \mathrm{H}, \mathrm{N}-\mathrm{CH}-\mathrm{CCl}\right)$, $\delta 8.52$ (dd, $J=5.6,1.4,1 \mathrm{H}, \mathrm{N}-\mathrm{CH}-\mathrm{C}$ ), $\delta 7.55$ (ddd, $\mathrm{J}=8.2,2.4$, $1.4,1 \mathrm{H}, \mathrm{CCl}-\mathrm{CH}-\mathrm{C}$ ), $\delta 7.50$ (t, $\mathrm{J}=2.4,2 \mathrm{H}, \mathrm{Ar}-\mathrm{p}$ ), $\delta 7.35$ (d, $\mathrm{J}=7.8$,
$4 \mathrm{H}, \mathrm{Ar}-\mathrm{p}$ ), $\delta 7.14$ (s, 2H, N-CH-CH-N), $\delta 7.07$ (ddd, J = 8.2, 5.6, $0.5,1 \mathrm{H}, \mathrm{C}-\mathrm{CH}-\mathrm{C}$ ), $\delta 3.16$ (sept, $\mathrm{J}=6.8,2 \mathrm{H}$, me-CH-me), $\delta 1.48$ $\left(\mathrm{d}, \mathrm{J}=6.6,12 \mathrm{H},-\mathrm{CH}_{3}\right), \delta 1.12\left(\mathrm{~d}, \mathrm{~J}=6.9,12 \mathrm{H},-\mathrm{CH}_{3}\right)$.

1-Butyl-3-methylimidazolium bromide ([BMIM]Br) was synthesized according to a published procedure. ${ }^{[16 \mathrm{~d}]} 78.2 \mathrm{ml}(0.5$ mol) 1-methylimidazol and $97.9 \mathrm{ml}(0.9 \mathrm{~mol})$ 1-chlorobutane was dissolved in $100 \mathrm{ml} \mathrm{CH}{ }_{3} \mathrm{CN}$ in a Schlenk flask under argon and refluxed for $80 \mathrm{~h}$ (completion of the reaction confirmed by TLC). The reaction mixture was then transferred by cannula to another Schlenk flask containing $500 \mathrm{ml}$ well-stirred ethyl acetate and a seed crystal. Subsequently, the flask was cooled to $-30{ }^{\circ} \mathrm{C}$ for 2 $\mathrm{h}$, the solvent mixture removed by cannula filtration and the solid product dried under vacuum. Yield $161.5 \mathrm{~g}(>99 \%)$. ${ }^{1} \mathrm{H}$ NMR data corresponded to published data: ${ }^{[16 d]}{ }^{1} \mathrm{H}$ NMR $\left(400 \mathrm{MHz}, \mathrm{CDCl}_{3}\right) \delta$ 10.8 (s, $1 \mathrm{H}, \mathrm{N}-\mathrm{CH}-\mathrm{N}), \delta 7.22$ (d, J = 14.0, 2H, N-CH-CH-N), $\delta 4.32$ $\left(\mathrm{t}, \mathrm{J}=7.6,2 \mathrm{H}, \mathrm{N}-\mathrm{CH}_{2}-\mathrm{C}\right), \delta 4.12\left(\mathrm{~s}, 3 \mathrm{H}, \mathrm{N}-\mathrm{CH}_{3}\right) \delta 1.91$ (d, J = 7.6, $\left.2 \mathrm{H}, \mathrm{C}-\mathrm{CH}_{2}-\mathrm{C}\right), \delta 1.38\left(\mathrm{t}, \mathrm{J}=7.6,2 \mathrm{H}, \mathrm{C}-\mathrm{CH}_{2}-\mathrm{Me}\right), \delta 0.97(\mathrm{t}, \mathrm{J}=$ $\left.7.4,3 \mathrm{H}, \mathrm{C}-\mathrm{CH}_{3}\right)$.

\section{Catalytic tests}

All catalytic reactions were performed as duplicated experiments in a $100 \mathrm{~mL}$ magnetically stirred Berghof reactor or a $300 \mathrm{~mL}$ mechanically stirred Parr reactor, both with stirring and internal temperature control. For each reaction, the reactor was loaded with catalyst, IL, internal standard, substrate and solvent and flushed three times with $\mathrm{CO}$ gas before charged with a $\mathrm{CO} / \mathrm{O}_{2}$ (9:1) gas mixture unless otherwise stated. CAUTION: Note that the $\mathrm{CO} / \mathrm{O} 2$ gas ratio is within the flammability range $\left(15.5-94 \%{ }^{[30]}\right)$ and should never be applied without taking the due safety precautions.

In an typical experiment with the Berghof reactor, the reactor was loaded with $1.22 \mathrm{~g}(7.5 \mathrm{mmol})$ [BMIM]Cl, $4.0 \mathrm{mg}(6 \mu \mathrm{mol})$ $\mathrm{Pd}\left(\mathrm{PPh}_{3}\right) \mathrm{Cl}_{2}, 10.6 \mathrm{ml}$ toluene, $0.55 \mathrm{ml}(6 \mathrm{mmol})$ aniline, $84 \mu \mathrm{L}(0.6$ $\mathrm{mmol}$ ) mesitylene as internal standard, 9 bar $\mathrm{CO}, 1$ bar $\mathrm{O}_{2}$ and heated to $140{ }^{\circ} \mathrm{C}$ under stirring at $1000 \mathrm{rpm}$. In all experiments, the liquid volume in the reactor was constant at $12.4 \mathrm{ml}$ and the heating block preheated to $150^{\circ} \mathrm{C}$ before the charged reactor was inserted. The reaction time was measured from the onset of set temperature, which was reached in $30 \mathrm{~min}$. Temperature deviations from the set temperature were within $\pm 3^{\circ} \mathrm{C}$. After a desired reaction time, the heating block was removed and the reactor cooled to room temperature in an ice bath. Afterwards, the pressure was released and the solvent and IL phases separated.

In an typical experiment with the Parr reactor, the reactor was loaded with $2.34 \mathrm{~g}(15 \mathrm{mmol})$ [BMIM]Cl, $8.1(12 \mu \mathrm{mol}) \mathrm{mg}$ $\mathrm{Pd}\left(\mathrm{PPh}_{3}\right) \mathrm{Cl}_{2}, 22.2 \mathrm{ml}$ toluene, $1.1 \mathrm{ml}(12 \mathrm{mmol})$ aniline, $168 \mu \mathrm{L}$ $(0.12 \mathrm{mmol})$ mesitylene as internal standard, 9 bar $\mathrm{CO}, 1$ bar $\mathrm{O}_{2}$ and heated to $140{ }^{\circ} \mathrm{C}$ under stirring at $500 \mathrm{rpm}$. In all experiments, the liquid volume in the reactor was constant at $25.8 \mathrm{ml}$. The reaction time was measured from the onset of set temperature, which was reached in $1 \mathrm{~h}$. Temperature deviations from the set temperature were within $\pm 3^{\circ} \mathrm{C}$. After a desired reaction time, the heating mantle was removed and the reactor cooled to room temperature in an ice bath. Afterwards, the pressure was released and the solvent and IL phases separated. 


\section{Analysis}

Samples of the solvent and IL phases were analyzed by GC-MS and ${ }^{1} \mathrm{H}$ NMR, respectively. Aniline conversion was quantified using the internal standard method with mesitylene as internal standard. ${ }^{1} \mathrm{H}$ NMR spectra was measured in DMSO- $\mathrm{d}_{6}$ and collected with a relaxation time of two times T1. Product yield of diphenylurea and aniline conversion was quantified using the internal standard method with [BMIM]Cl.

\section{Acknowledgements}

The authors are grateful to the Ministerio de Economia y Competividad and the Fondo Europeo de Desarrollo Regional FEDER (CTQ2016-75016-R, AEI/FEDER, UE), the Generalitat de Catalunya (SGR2014), the Universitat Rovira I Virgili (MartiFranques grant ref. 2013PMF-PIPF-89(0)) for funding and to the staff at Servei de Recursos Científics i Tècnics of the URV for assistance with sample analysis.

Keywords: Aniline $\cdot$ diphenylurea $\bullet$ ionic liquids $\bullet$ oxidative carbonylation $\cdot$ palladium

[1] D. J. Díaz, A. K. Darko, L. McElwee-White, European J. Org. Chem. 2007, 2007, 4453-4465.

[2] F. Calderazzo, Inorg. Chem. 1965, 4, 293-296.

[3] K. L. Dunlap, Kirk-Othmer Encycl. Chem. Technol. 2010, 1-13.

[4] a) D. J. Díaz, K. G. Hylton, L. McElwee-White, J. Org. Chem. 2006, 71, 734-738. b) P. Shelton, Y. Zhang, T. H. H. Nguyen, L. McElweeWhite, Chem. Commun. 2009, 1, 947-9. c) I. Pri-bar, H. Alper, Can. J. Chem. 1989, 68, 1544. d) M. Aresta, P. Giannoccaro, I. Tommasi, A. Dibenedetto, A. Maria, M. Lanfredi, F. Ugozzoli, A. M. Manotti Lanfredi, F. Ugozzoli, M. Lanfredi, F. Ugozzoli, A. M. Manotti Lanfredi, F. Ugozzoli, Organometallics 2000, 1995, 3879-3889. e) J. E. Mccusker, F. Qian, L. Mcelwee-white, J. Mol. Catal. A Chem. 2000, 159, 11-17. f) J. E. Mccusker, C. A. Grasso, A. D. Main, L. Mcelweewhite, V. Uni, V. Gaines, Org. Lett. 1999, 1, 4155-4158.

[5] a) M. Casiello, F. lannone, P. Cotugno, A. Monopoli, N. Cioffi, F. Ciminale, A. M. Trzeciak, A. Nacci, J. Mol. Catal. A Chem. 2015, 407, 8-14. b) F. Shi, Y. Deng, J. Catal. 2002, 211, 548-551. c) B. Zhu, R. J. Angelici, J. Am. Chem. Soc. 2006, 128, 14460-14461. d) A. Orejón, A. M. Masdeu-Bultó, P. Salagre, S. Castillón, C. Claver, A. Padilla, B. Almena, F. L. Serrano, Ind. Eng. Chem. Res. 2008, 47, 8032-8036. e) F. Saliu, B. Putomatti, B. Rindone, Tetrahedron Lett. 2012, 53 , 3590-3593. f) P. Giannoccaro, C. F. Nobile, P. Mastrorilli, N. Ravasio, J. Organomet. Chem. 1991, 419, 251-258. g) S. A. R. Mulla, S. P. Gupte, R. V. Chaudhari, J. Mol. Catal. 1991, 67, L7-L10. h) S. Kanagasabapathy, S. P. Gupte, R. V Chaudhari, Ind. Eng. Chem. Res. 1994, 33, 1-6. i) X. Peng, F. Li, X. Hu, C. Xia, C. a. Sandoval, Chinese J. Catal. 2008, 29, 638-642. j) S.-Z. Z. Zheng, X.-G. G. Peng, J.-M. M. Liu, W. Sun, C.-G. G. Xia, Chinese J. Chem. 2007, 25, 10651068. k) R. Mancuso, D. S. Raut, N. Della Ca', F. Fini, C. Carfagna, B. Gabriele, ChemSusChem 2015, 8, 2204-2211. I) N. Della Ca', P. Bottarelli, A. Dibenedetto, M. Aresta, B. Gabriele, G. Salerno, M.
Costa, J. Catal. 2011, 282, 120-127. m) M. R. Didgikar, S. S. Joshi, S. P. Gupte, M. M. Diwakar, R. M. Deshpande, R. V. Chaudhari, J. Mol. Catal. A Chem. 2011, 334, 20-28. n) B. Gabriele, R. Mancuso, G. Salerno, M. Costa, Chem. Commun. 2003, 486-487. o) B. Gabriele, G. Salerno, R. Mancuso, M. Costa, J. Org. Chem. 2004, 69, 4741-4750. p) P. Giannoccaro, J. Organomet. Chem. 1987, 336, 271-278. q) P. Giannoccaro, C. Ferragina, M. Gargano, E. Quaranta, Appl. Catal. A Gen. 2010, 375, 78-84.

a) J. Tsuji, N. Iwamoto, Chem. Commun. 1966, 380. b) H. Alper, G. Vasapollo, F. W. Hartstock, M. Mlekuz, Organometallics 1987, 6, 2391-2393. c) V. L. K. Valli, H. Alper, Organometallics 1996, 14, 8082. d) K. Hiwatari, Y. Kayaki, K. Okita, T. Ukai, I. Shimizu, A. Yamamoto, Bull. Chem. Soc. Jpn. 2004, 77, 2237-2250. e) K. D. Kim, S. M. Lee, N. S. Cho, J. S. Oh, J. Mol. Catal. 1992, 75.

[7] W. Brackman, Discuss. Faraday Soc 1968, 122-126.

[8] X. Wang, P. Li, X. Yuan, S. Lu, J. Mol. Catal. A Chem. 2006, 255, 2527.

[9] a) J. Chen, S. Lu, Appl. Catal. A Gen. 2004, 261, 199-203. b) H. S. Kim, Y. J. Kim, H. Lee, S. D. Lee, C. S. Chin, J. Catal. 1999, 534, 526-534. c) S. Hwang, H. S. Kim, M. Cheong, Bull. Korean Chem. Soc. 2012, 33, 3864-3866. d) X. Zhang, H. Jing, G. Zhang, Synth. Commun. 2010, 40, 1614-1624.

[10] a) A. Krogul, J. Skupińska, G. Litwinienko, J. Mol. Catal. A Chem. 2011, 337, 9-16. b) A. Krogul, G. Litwinienko, J. Mol. Catal. A Chem. 2015, 407, 204-211.

[11] P. A. Jäger, C. N. Rentzea, H. Kieczka, in Ullmann's Encycl. Industrial Chemistry, Wiley-VCH, Weinheim, 2012, pp. 553-560.

[12] a) N. V. Plechkova, K. R. Seddon, Eds., Ionic Liquids UnCoiled: Critical Expert Overviews. Wiley \& Sons, Inc., Hoboken, 2012. b) N. V. Plechkova, K. R. Seddon, Eds., Ionic Liquids Complety Uncoiled: Critical Expert Overviews. Wiley \& Sons, Inc., Hoboken, 2015. c) R. Fehrmann, A. Riisager, M. Haumann, Eds., Supported lonic Liquids: Fundamentals and Applications, Wiley-VCH Verlag $\mathrm{GmbH} \& \mathrm{Co}$. KGaA, 2014. d) V. I. Pârvulescu, C. Hardacre, Chem. Rev. 2014, 107, 2615. e) Z. Gui, N. Zahrtmann, S. Saravanamurugan, I. Reyero, Z. Qi, M. A. Bañares, A. Riisager, E. J. Garcia-Suarez, Chem. Sel. 2016, 1, 5869-5873.

[13] F. Amoroso, E. Zangrando, C. Carfagna, C. Muller, D. Vogt, M. Hagar, F. Ragaini, B. Milani, Dalt. Trans. 2013, 42, 14583-14602.

[14] a) Z. Lei, C. Dai, B. Chen, Chem. Rev. 2014, 114, 1289-1326. b) K. Fischer, M. Wilken, J. Chem. Thermodyn. 2001, 33, 1285-1308. [15] T. Hoshino, T. Mukaiyama, H. Hoshin, J. Am. Chem. Soc. 1952, 115, 18-21.

[16] a) M. S. Viciu, R. M. Kissling, E. D. Stevens, S. P. Nolan, Org. Lett. 2002, 4, 2229-2231. b) B. J. V Verkuijl, W. Szyman, B. Wu, A. J. Minnaard, D. B. Janssen, J. G. de Vries, B. L. Feringa, Chem. Commun. 2010, 46, 901-903. c) A. Bontempi, E. Alessio, G. Chanos, G. Mestroni, J. Mol. Catal. 1987, 42, 67-80. d) J. Dupont, C. S. Consorti, P. A. Z. Suarez, R. F. de Souza, Org. Synth. 2002, 79, 236. e) A. R. Mulla, S. P. Gupte, V. Chaudhari, 1991, 67, 7-10. f) J. Tsuji, H. Guo, Encycl. Reagents Org. Synth. 2015, 1-27. g) H. Lebel, M. K. Janes, A. B. Charette, S. P. Nolan, J. Am. Chem. Soc. 2004, 126, 5046-5047. h) L.-C. Campeau, P. Transandote, K. Fagnou, Org. Lett. 2005, 7, 1857-1860. i) V. L. K. Valli, H. Alper, Organometallics 1996, 
14, 80-82.

[17] F. Shi, J. Peng, Y. Deng, J. Catal. 2003, 219, 372-375.

[18] a) J. C. C. Chen, I. J. B. Lin, Organometallics 2000, 19, 5113-5121. b) M. G. Gardiner, W. A. Herrmann, C. Reisinger, J. Schwarz, M. Spiegler, J. Organomet. Chem. 1999, 572, 239-247. c) M. M. Konnick, I. A. Guzei, S. S. Stahl, J. Am. Chem. Soc. 2004, 126, 10212-10213. d) S. S. Stahl, Science (80-. ). 2005, 309, 1824-1826. e) M. M. Konnick, N. Decharin, B. V. Popp, S. S. Stahl, Chem. Sci. 2011, 2, 326-330. f) M. M. Konnick, S. S. Stahl, J. Am. Chem. Soc. 2008, 130, 5753-5762. g) M. M. Konnick, B. A. Gandhi, I. A. Guzei, S. S. Stahl, Angew. Chemie - Int. Ed. 2006, 45, 2904-2907.

[19] A. N. Gómez-Suárez, S. P. Nolan, D. J. Nelson, Chem. Commun. 2017, 53, 2650-2660.

[20] a) I. del Río, C. Claver, P. W. N. M. van Leeuwen, Eur. J. Inorg. Chem. 2001, 2719-2738. b) D. M. Norton, E. A. Mitchell, N. R. Botros, P. G. Jessop, M. C. Baird, J. Org. Chem. 2009, 74, 6674-6680.

[21] L. Luza, A. Gual, C. P. Rambor, D. Eberhardt, S. R. Teixeira, F. Bernardi, D. L. Baptista, J. Dupont, Phys. Chem. Chem. Phys. 2014, 16, 18088-18091.

[22] A. R. C. Morais, A. M. da Costa Lopes, E. Bogel-Łukasik, R. BogelŁukasik, Ind. Eng. Chem. Res. 2013, 52, 14722-14726.

[23] a) S. Tsuzuki, M. Mikami, Phys. Chem. Chem. Phys. 2007, 9, 47804784. b) E. I. Izgorodina, D. Golze, R. Maganti, V. Armel, M. Taige, T. J. S. Schubert, D. R. MacFarlane, Phys. Chem. Chem. Phys. 2014, 16, 7209-7221.

[24] T. Yamada, Y. Tominari, S. Tanaka, M. Mizuno, J. Phys. Chem. B 2015, 119, 15696-15705.

[25] G. R. Fulmer, A. J. M. Miller, N. H. Sherden, H. E. Gottlieb, A. Nudelman, B. M. Stoltz, J. E. Bercaw, K. I. Goldberg, Organometallics 2010, 29, 2176-2179.

[26] X. Bantreil, S. P. Nolan, Nat. Protoc. 2011, 6, 69-77.

[27] A. J. Arduengo, R. Krafczyk, R. Schmutzler, H. A. Craig, J. R. Goerlich, W. J. Marshall, M. Unverzagt, Tetrahedron 1999, 55, 14523-14534.

[28] L.Pazderski, E. Szlyk, J. Sitkowski, B. Kamienski, L. Kozerski, J. Tousek, R. Marek, Magn. Reson. Chem. 2006, 44, 163-170.

[29] C. J. O. Brien, A. B. Kantchev, C. Valente, N. Hadei, G. A. Chass, A. Lough, A. C. Hopkinson, M. G. Organ, Chem. a Eur. J. 2006, 12, 4743-4748.

[30] B. Lewis, G. von Elbe, in Combustion, Flames Explosions of Gases, $3^{\text {th }}$ Ed. (Eds.: B. Lewis, G. von Elbe), Academic Press, Orlando, 1987, pp. 705-716.
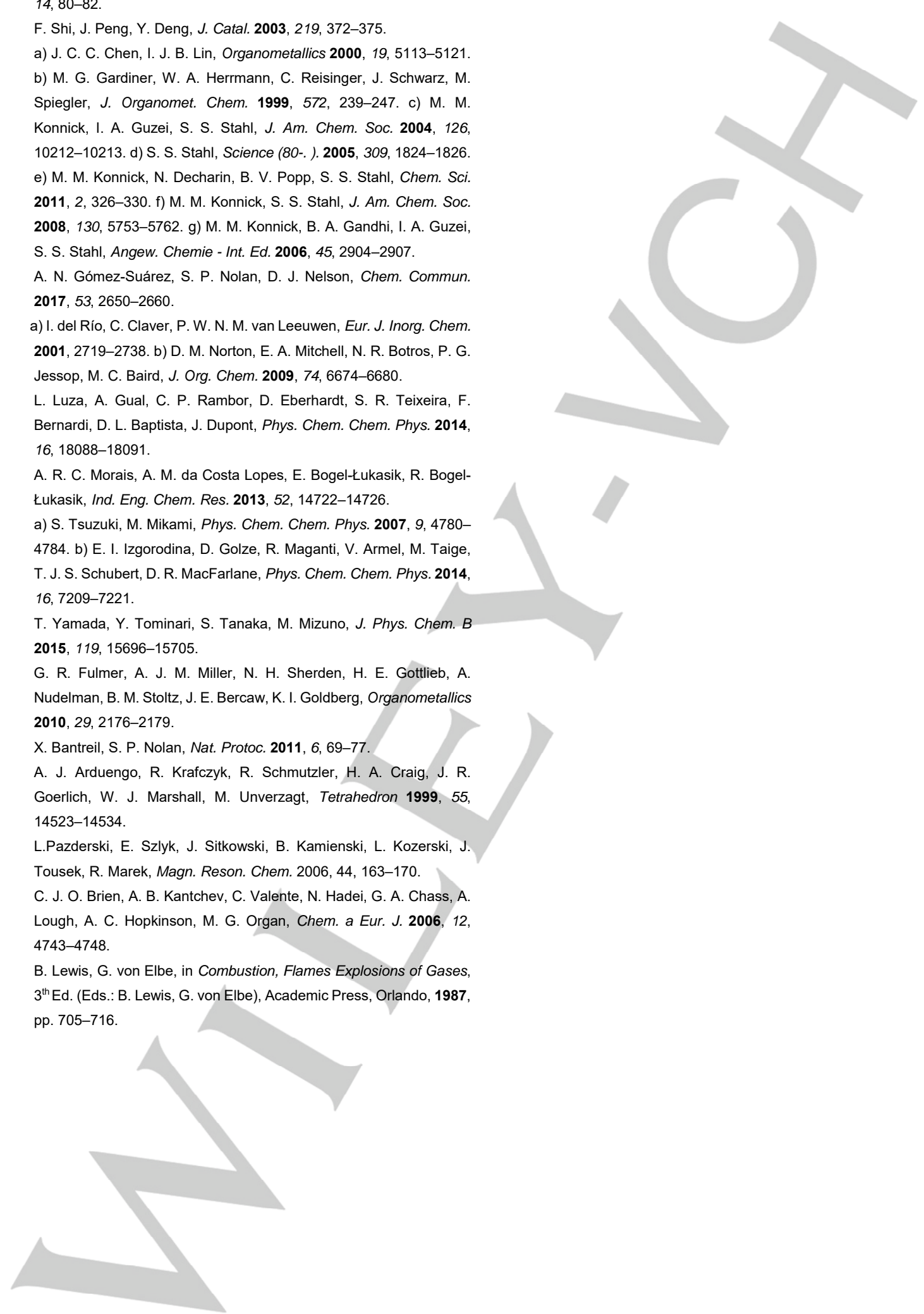
Entry for the Table of Contents (Please choose one layout)

\section{FULL PAPER}

Ionic Liquid as promotor - Pdcomplex systems in combination with imidazolium ionic liquids catalyze the selective oxidative carbonylation of aniline with unprecedented activity under relatively mild conditions. In-situ NMR study of the reaction system led to observation of an only previously suggested Pd-intermediate.
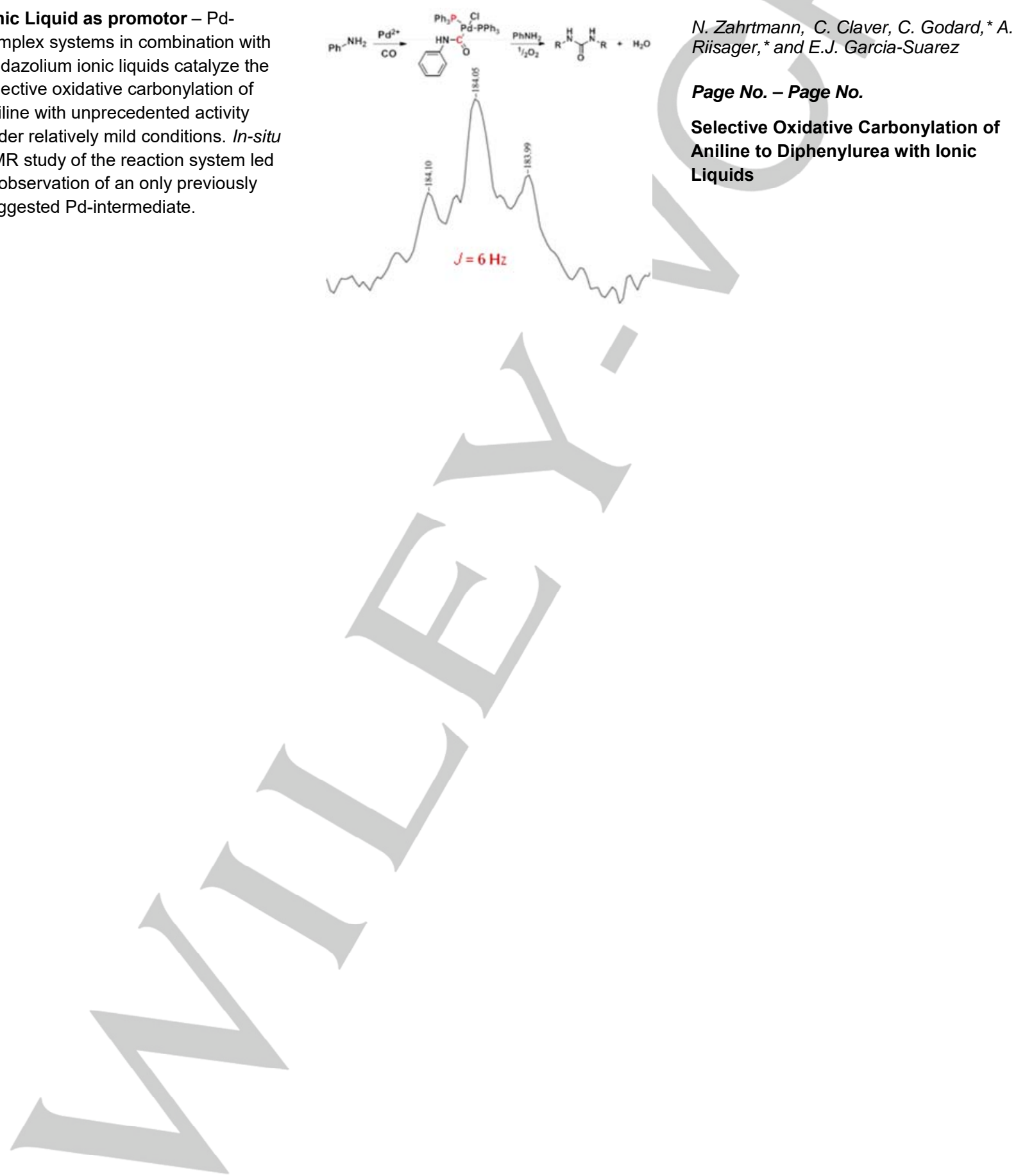